\title{
Impact of Traditional Treatments on the Nutritional Value of Seeds of Jack Fruit (Artocarpus heterophyllus)
}

\author{
O. E. Ezim ${ }^{1}$, L. U. S. Ezeanyika ${ }^{2}$, C. U. O. Ujowundu ${ }^{3}$ \\ ${ }^{1}$ Department of Biochemistry, University of Port Harcourt, Port Harcourt, Rivers State, Nigeria \\ ${ }^{2}$ Department of Biochemistry, University of Nigeria, Nsukka, Nigeria \\ ${ }^{3}$ Department of Biochemistry, Federal University of Technology Owerri, Owerri, Imo State, Nigeria \\ Email: *ogechukwu.okafor@uniport.edu.ng
}

How to cite this paper: Ezim, O.E., Ezeanyika, L.U.S. and Ujowundu, C.U.O. (2020) Impact of Traditional Treatments on the Nutritional Value of Seeds of Jack Fruit (Artocarpus heterophyllus). Food and Nutrition Sciences, 11, 983-989.

https://doi.org/10.4236/fns.2020.1111069

Received: March 3, 2020

Accepted: November 9, 2020

Published: November 12, 2020

Copyright $\odot 2020$ by author(s) and Scientific Research Publishing Inc. This work is licensed under the Creative Commons Attribution International License (CC BY 4.0).

http://creativecommons.org/licenses/by/4.0/

\begin{abstract}
Impact of traditional treatments on the nutritional value of Artocarpus heterophyllus seeds was evaluated. Four traditional processing methods were used (boiling, roasting, soaking and fermentation). Boiled A. heterophyllus (BAH) samples were boiled in water for 60 minutes, roasted $A$. heterophyllus (RAH) samples were roasted in fine sand, soaked $A$. heterophyllus (SAH) were soaked in clean water for 48 hours before boiling while the fermented $A$. heterophyllus (FAH) samples were boiled and wrapped in black bag for 48 hours. The mean proximate content (\%) of the unprocessed $A$. heterophyllus (UAH) seeds was; protein $(15.88 \pm 0.08)$, fibre $(10.04 \pm 0.09)$ ash $(5.05 \pm$ $0.07)$, moisture $(29.25 \pm 0.35)$, fat $(10.26 \pm 0.35)$ and carbohydrate $(29.52 \pm$ 0.4). Processing affected the proximate and mineral composition of $A$. heterophyllus seeds. All the processing methods used reduced the protein content. There were significant increases $(\mathrm{p}<0.05)$ in manganese $(\mathrm{Mn})$, magnesuim $(\mathrm{Mg})$, potassium $(\mathrm{K})$, copper $(\mathrm{Cu})$, iron $(\mathrm{Fe})$, iodine $(\mathrm{I})$, chlorine $(\mathrm{Cl})$ and phosphorous $(\mathrm{P}) \mathrm{BAH}$ and $\mathrm{SAH}$ samples and a significant reduction ( $\mathrm{p}<0.05)$ in $\mathrm{Mg}$, calcium (Ca), selenium (Se), $\mathrm{Cu}, \mathrm{Cl}$, zinc $(\mathrm{Zn})$ and $\mathrm{Mn}$ in FAH sample. Processing increased the level of phosphorous in all the samples. A. heterophyllus seeds are rich in nutrient and can serve as an alternative source of nutrients for both man and animals.
\end{abstract}

\section{Keywords}

Jack Fruit, Minerals, Processing, Proximate Composition

\section{Introduction}

Plant based foods offer an array of nutrients that are essential for human nutri- 
tion and promotion of good health. Most third world countries depend for basic diet of carbohydrates, fats and proteins on a very limited number of crop species that are conventional [1]. The Food and Agriculture Organization (FAO) of the World Health Organization (WHO) estimated that between 1990 and 1992, 204 million sub-Saharan Africans ( $41 \%$ of the population of the region) were chronically undernourished.

The WHO (1995) estimates for iodine, vitamin A and iron deficiencies in Africa show that 181 million Africans were at risk of iodine deficiency, 1 million had xerophthalmia, while 206 million had iron deficiency or anaemia [2] [3].

Across the world, many of the plant species that are cultivated for food are neglected and underutilized while they play a crucial role in the food security, nutrition, and income generation of the rural poor [4] [5]

A. heterophyllus (Jack Fruit) belongs to the family of moraceae (mulberry family). Jack fruit tree bears fruits all-round the year with peak production during the months of June and December. It is one of the underutilized plant species in Nigeria. Over $90 \%$ of the seeds are wasted annually; the ripe fruits are chewed while the seeds are discarded; only few populations consume the boiled and roasted seeds.

This study aimed at assessing the effects of various traditional processing methods on the proximate and mineral composition of A. heterophyllus seeds, with the aim of identifying the method(s) that preserve the nutrients and minerals.

\section{Experimental Section}

The fresh fruits of $A$. heterophyllus were bought from Eke Umuoji market in Idemili Local Government Area of Anambra State, Nigeria. The fruits were opened; the seeds were sorted and the bad ones were discarded. The raw seeds were divided into five equal portions and each part was processed by one of the following methods: boiling, roasting, soaking and fermentation while the fifth part was unprocessed. The Boiled A. heterophyllus (BAH) samples were prepared by boiling the seeds in clean water for 60 minutes, the seed coats were then removed and the seeds dried. The roasted A. heterophyllus (RAH) samples were prepared by roasting the seeds in fine sand for 60 minutes, after which the seed coats were removed and the seeds dried. Soaked $A$. heterophyllus (SAH) were prepared by soaking the seeds in clean water for 48 hours (the water was changed at 24 hours intervals), the soaked seeds were then boiled for 60 minutes and dried. Fermented $A$. heterophyllus (FAH) samples were prepared by boiling the seeds for 60 minutes, after which the seed coats were removed and the seeds tied in black nylon and kept in a cupboard for 48 hours. Drying of seeds (to a constant weight) was done in a laboratory oven at $50^{\circ} \mathrm{C}$. The processed seeds were ground into fine powder using a laboratory mill and fractions of each were used for the analysis of their constituents

\subsection{Proximate Analysis}

Moisture, lipid, ash and crude fibre contents were determined following the 
standard methods of the Association of Official Analytical Chemists [6]. The organic nitrogen content was quantified using the micro Kjeldahl method, and an estimate of the crude protein content was done by multiplying the organic nitrogen content by a factor of 6.25 [7]. Total carbohydrate content was calculated by difference.

\subsection{Determination of Minerals}

Calcium, potassium, manganese, selenium, copper, magnesium, iron, zinc and sodium were determined using FS 240 Varian atomic absorption spectrophotometry method while iodine, chloride and phosphorous were determined by colorimetric methods.

\subsection{Statistical Analysis}

Data generated from the study were analysed and the results presented as mean \pm standard deviation of three determinations. Differences between means were separated using ANOVA and multiple comparison tests, with the least significant difference fixed at 0.05 .

\section{Results and Discussion}

\subsection{Seeds Nutritional Characterization}

From the result in Table 1, the proximate composition of UAH and BAH differed numerically from the report of other workers; some researchers reported protein $27.57 \%, 4.03 \%$ and fibre $4.0 \%$ ash, for $\mathrm{UAH}$ and $22.93 \%$ protein, $3.65 \%$ fibre, $3.39 \%$ ash, for $\mathrm{BAH}$ [8]. Another researcher reported $15.10 \%$ protein, $6.09 \%$ fibre, $3.79 \%$ ash, $12.34 \%$ moisture, $1.2 \%$ fat and $61.36 \%$ carbohydrate for A. heterophyllus seed cake [9]. Another reported $14.81 \%$ protein, $17.90 \%$ starch, $3.83 \%$, fibre, $2.13 \%$ ash and $42.25 \%$ moisture for UAH seeds [10]. In this study, the values obtained were; $15.88 \%$ protein, $10.04 \%$ fibre, $5.05 \%$ ash, $22.25 \%$ moisture, $10.26 \%$ fat and $36.54 \%$ carbohydrate for UAH. It has been established that nutrient and antinutrient compositions may vary depending on the variety, growing conditions, geographical location and the propagation method of the seeds. When compared with conventional seeds like African bread fruit, bread

Table 1. Nutrient composition of A. heterophyllus seeds subjected to different processing methods.

\begin{tabular}{cccccc}
\hline $\begin{array}{c}\text { Percentage } \\
\text { composition }\end{array}$ & $\begin{array}{c}\text { Unprocessed } \\
\text { (UAH) }\end{array}$ & Roasted (RAH) & Boiled (BAH) & Soaked (SAH) & $\begin{array}{c}\text { Fermented } \\
\text { (FAH) }\end{array}$ \\
\hline Protein & $15.88 \pm 0.08$ & $11.95 \pm 0.07$ & $9.9 \pm 0.04$ & $11.78 \pm 0.06$ & $10.75 \pm 0.15$ \\
Fibre & $10.04 \pm 0.09$ & $12.04 \pm 0.04$ & $4.55 \pm 0.064$ & $8.05 \pm 0.05$ & $5.06 \pm 0.082$ \\
Ash & $5.05 \pm 0.07$ & $6.03 \pm 0.04$ & $4.04 \pm 0.05$ & $6.70 \pm 0.05$ & $3.03 \pm 0.037$ \\
Moisture & $29.25 \pm 0.35$ & $20.05 \pm 0.35$ & $19.95 \pm 0.8$ & $20.46 \pm 0.71$ & $35.04 \pm 0.39$ \\
Fat & $10.26 \pm 0.35$ & $9.55 \pm 0.7$ & $9.98 \pm 0.38$ & $9.07 \pm 0.93$ & $8.49 \pm 0.25$ \\
Carbohydrate & $29.52 \pm 0.4$ & $40.38 \pm 0.69$ & $51.58 \pm 0.44$ & $43.95 \pm 0.42$ & $37.64 \pm 1.27$ \\
\hline
\end{tabular}


fruit and bambara nut, $A$. heterophyllus raw/unprocessed seeds protein amounts to $15.88 \%$ this is higher than African bread (Treculiar africana) fruit $12 \%$, and bread fruit (Artocarpus atilis) $8.42 \%$ but lower than bambara nut $23.41 \%$ and pigeon pea $21.88 \%$.

Processing affected the proximate composition of A. heterophyllus seeds. All the processsing methods used reduced the protein content. BAH had the least protein content $9.9 \%$ while roasted $A$. heterophyllus (RAH) had the highest value. The significant decrease $(\mathrm{p}<0.05)$ in protein content of BAH might be due to leaching out of soluble nitrogen into the solution, this agrees with the report of Ijeh et al. [3], they reported a reduction of protein content of bread fruit after boiling.

The decreased in protein content of fermented A. heterophyllus (FAH) seeds might be because the microbial flora used some of the protein for their metabolic activity while reduction in RAH might be due to denaturation of endogenous proteins in the seeds during processing.

The fibre content of $A$. heterophyllus seeds was high (10.04\%) compared to other conventional seeds, Ijeh reported $1.3 \%$ for African bread fruit [3], Isichei and Achinewhu reported 2.5\% for African oil bean and melon seeds [11], while Akpabio reported $3.11 \%$ for almond seeds [12]. High fibre could trap and protect a large proportion of nutrients such as protein and carbohydrate from hydrolytic breakdown, thus reducing digestibility and utilization of end product of digestion. Dietary fibre also slows gastric emptying time by forming a gel matrix in the small intestine, it enhances bile salt and cholesterol excretion and increase faecal bulk and faecal transit time through the bowel [13]. The gel matrix slows absorption by trapping nutrients, digestive enzymes or bile acids. This effect is a characteristic which is necessary to blunt the increase in plasma glucose after a glucose load. Thus, the high dietary fibre of $A$. heterophyllus seeds could be exploited for the therapeutic management of conditions such as hyperglycaemia and hypercholesterolaemia in humans. Roasting increased the crude fibre content of the seed to $12.04 \%$, this agrees with the work of Ijeh et al. [3] in a report that showed an increase in fibre content of roasted African bread fruit.

The high fat content of UAH seeds (10.25\%) makes it a potential source of vegetable oil. The fat content is higher than that of African bread fruit (4.23\%). It was observed that processing reduced the fat content of all the samples, this might be because some of the oil might have leached out in cooking water and some lost during roasting. The observation is in line with the report of Ijeh [3], where reduction in fat content was observed following boiling and roasting, Oyeike also reported reduction in fat content of boiled and fried groundnut seeds [14].

The moisture content showed that RAH seeds had the least value (19.95\%) while the fermented samples had the highest value (35.04\%). This suggests that roasted samples can be stored for a long time without spoilage since higher water activity can enhance microbial action thereby causing food spoilage [15].

Total carbohydrate value was increased in all the samples when compared with UAH seeds. Fermentation had the least value $37.64 \%$ while the boiled sam- 
ple had the highest value $47.89 \%$.

\subsection{Seeds Mineral Characterization}

The mineral compositions of $A$. heterophyllus seeds in Table 2, showed that magnesium level $(\mathrm{mg} / \mathrm{kg})$ was highest in UAH (29.51), followed by calcium; UAH (16.61). Among the trace element, selenium was the highest; UAH (5.3), followed by zinc; UAH (16.61).

Processing affected the levels of minerals in A. heterophyllus seeds. There was reduction in $\mathrm{Mg}, \mathrm{Ca}, \mathrm{Se}, \mathrm{Cu}, \mathrm{Cl}, \mathrm{Zn}$ and $\mathrm{Mn}$ in $\mathrm{FAH}$. These decrease observed with fermentation method could be due to the probability of the mineral being used for microbial metabolism. This is in line with the report of Afify, they reported reduction in $\mathrm{Mg}, \mathrm{Cu}, \mathrm{Zn}$ and $\mathrm{Mn}$ levels of fermented white sorghum varieties. There was increase in $\mathrm{Mn}, \mathrm{Mg}, \mathrm{K}, \mathrm{Cu}, \mathrm{Mg}, \mathrm{Fe}, \mathrm{I}, \mathrm{Cl}$ and $\mathrm{P}$ in $\mathrm{BAH}$ and $\mathrm{SAH}$ samples. This might be attributed to the source of water for processing. Adane reported increase in $\mathrm{Fe}, \mathrm{Ca}, \mathrm{Na}, \mathrm{Mg}, \mathrm{Cu}$ and $\mathrm{P}$ levels of boiled Colocasiaesculenta [16]. There was increase in $\mathrm{Mn}, \mathrm{Mg}, \mathrm{Cu}, \mathrm{I}, \mathrm{Cl}$ and $\mathrm{P}$ in RAH sample. This result is in agreement with Ijeh report's of an increase in $\mathrm{Ca}, \mathrm{Mg}, \mathrm{Cu}$ and I in roasted Treculia africana seeds [3]. Fe was not detected in FAH while $\mathrm{K}$ and Fe were not detected in RAH. Processing increased the level of phosphorous in all the treatments, these increase might be due to breakdown of phytate by phytase to release more phosphorous. Fermentation increased the phosphorous level more than other treatments (Table 3).

Table 2. Mineral content of $A$. heterophyllus SEEDS (Mg/G) subjected to different processing methods.

\begin{tabular}{cccccc}
\hline Minerals (mg/kg) & $\begin{array}{c}\text { Unprocessed } \\
\text { (UAH) }\end{array}$ & Boiled (BAH) & $\begin{array}{c}\text { Roasted } \\
(\mathrm{RAH})\end{array}$ & Soaked (SAH) & $\begin{array}{c}\text { Fermented } \\
(\mathrm{FAH})\end{array}$ \\
\hline Manganese & $0.42 \pm 0.01$ & $1.13 \pm 0.03$ & $1.08 \pm 0.13$ & $1.63 \pm 0.041$ & $0.11 \pm 0.0$ \\
Potassium & $0.09 \pm 0.01$ & $0.68 \pm 0.01$ & 0.00 & $0.62 \pm 0.023$ & $0.68 \pm 0.01$ \\
Calcium & $16.61 \pm 0.021$ & $16.27 \pm 0.01$ & $7.06 \pm 0.01$ & $16.5 \pm 0.17$ & $13.88 \pm 0.11$ \\
Selenium & $5.3 \pm 0.01$ & $1.4 \pm 0.021$ & $2.11 \pm 0.02$ & $3.11 \pm 0.56$ & $2.2 \pm 0.05$ \\
Copper & $0.25 \pm 0.01$ & $0.31 \pm 0.01$ & $0.67 \pm 0.02$ & $0.58 \pm 0$ & $0.06 \pm 0.01$ \\
Magnesium & $29.51 \pm 0.02$ & $30.41 \pm 0.02$ & $29.76 \pm 0.03$ & $30.13 \pm 0.18$ & $30.41 \pm 0.21$ \\
Iron & $0.13 \pm 0.01$ & $5.2 \pm 0.01$ & 0.00 & $8.94 \pm 0.15$ & 0.00 \\
Zinc & $4.34 \pm 0.01$ & $4.28 \pm 0.01$ & $3.67 \pm 0.02$ & $4.35 \pm 0.062$ & $0.38 \pm 0.01$ \\
Sodium & $4.78 \pm 0.01$ & $2.31 \pm 0.01$ & $3.88 \pm 0.02$ & $3.89 \pm 0.06$ & $4.92 \pm 0.09$ \\
\hline
\end{tabular}

Table 3. Mineral content of $A$. heterophyllus seeds $(\mathrm{Mg} / \mathrm{L})$ subjected to different processing method.

\begin{tabular}{cccccc}
\hline Mineral (mg/l) & UAH & BAH & RAH & SAH & FAH \\
\hline Iodine & $10.39 \pm 0.31$ & $12.86 \pm 0.42$ & $12.11 \pm 0.52$ & $14.82 \pm 1.1$ & $13.31 \pm 1.09$ \\
Chloride & $19.15 \pm 0.7$ & $22.48 \pm 0.61$ & $38.33 \pm 1.4$ & $43.49 \pm 1.4$ & $11.49 \pm 0.83$ \\
Phosphorous & $0.75 \pm 0.02$ & $0.94 \pm 0.03$ & $1.00 \pm 0.01$ & $0.89 \pm 0.05$ & $1.33 \pm 0.081$ \\
\hline
\end{tabular}




\section{Conclusion}

In conclusion, the results showed that $A$. heterophyllus seeds are high in nutrients. Among the different traditional processing methods used, roasted samples had the highest nutrient compositions while the boiled samples had the least nutrient content. For the mineral elements, soaking of seeds preserved the mineral elements better than the other processing methods. Consumption of $A$. heterophyllus fruit should be encouraged and promoted. When promoted, they could contribute to poverty reduction mainly in rural areas, and to the improvement of nutritional status of the entire population. This will help to reduce over dependence on some conventional foods thus enhancing food availability and alleviating poverty.

\section{Acknowledgements}

The authors thank Nigeria Tertiary Education Trust Fund (TET fund) for their financial support and also Association of Commonwealth University (ACU) Early Careers Academic Grant for sponsorship to present this work in an international conference.

\section{Conflicts of Interest}

The authors declare no conflicts of interest regarding the publication of this paper.

\section{References}

[1] Mayes, S., Massawe, F.J., Alderson, P.G., Roberts, J.A., Azam-Ali, S.N. and Hermann, M. (2012) The Potential for Underutilized Crops to Improve Security of Food Production. Journal of Experimental Botany, 63, 1075-1079.

[2] Latham, M.C. (1997) Human Nutrition in the Developing World: Food and Nutrition Series-No. 29. Food and Agriculture Organization of the United Nations, Rome.

[3] Ijeh, I.I., Ejike, C.E., Nkwonta, O.M. and Njoku, B.C. (2010) Effect of Traditional Processing Techniques on the Nutritional and Phytochemical Composition of African Bread Fruit (Treculia africana) Seeds. Journal of Applied Science and Environmental Management, 4, 169-173. https://doi.org/10.4314/jasem.v14i4.63314

[4] Magbagbeola, J.A.O., Adetoso, J.A. and Owolabi, O.A. (2010) Neglected and Underutilized Species (NUS): A Panacea for Community Focused Development to Poverty Alleviation/Poverty Reduction in Nigeria. Journal of Economics and International Finance, 2, 208-211.

[5] Dansi, A., Vodouhè, R., Azokpota, P., Yedomonhan, H., Assogba, P., Adjatin, A., Loko, Y.L., Dossou-Aminon, I. and Akpagana, K. (2012) Diversity of the Neglected and Underutilized Crop Species of Importance in Benin. The Scientific World Journal, 2012, Article ID: 9232947. https://doi.org/10.1100/2012/932947

[6] Association of Official Analytical Chemists (1990) Official Methods of Analysis. 15th Edition, Association of Official Analytical Chemists, Washington DC.

[7] Sosulski, F.W. and Imafidon, G.I. (1990) Amino Acid Composition and Nitrogen-to-Protein Conversion Factors for Animal and Plant Foods. Journal of Agri- 
cultural and Food Chemistry, 38, 1351-1356. https://doi.org/10.1021/jf00096a011

[8] Akinmutimi, A.H. (2006) Nutritive Value of Raw and Processed Jack Fruit Seeds (Artocarpus heterophyllus): Chemical Analysis. Agricultural Journal, 1, 266-271.

[9] Ajayi, I.A. and Adewale, R.A. (2013) Amino Acid and Short Term Toxicological Evaluation of Artocarpus heterophyllus Seed Cake in Rat Diet. New York Science Journals, 6, 91-98.

[10] Abedin, M.S., Ahmed, K.U., Nuruddin, M.M. and Hossain, A.A. (2012) Nutritive Compositions of Locally Available Jack Fruit Seeds (Artocarpus heterophyllus) in Bangladesh. International Journal of Biosciences, 2, 1-7.

[11] Isichei, M.O. and Achinewhu, S.C. (1990) The Nutritional Evaluation of Fermented Fluted Pumpkin Seeds (Telferia occidentalis Hook). Discovery and Innovations, 2, 62-65.

[12] Akpabio, U.D. (2012) Evaluation of Proximate Composition, Mineral Element and Anti-Nutrient in Almond (Terminali aattapa) Seeds. Advances in Applied Science Research, 3, 2247-2252.

[13] Schneeman, B.O. (1987) Soluble vs. Insoluble Fibre: Different Physiological Responses. Food Technology, 41, 81-82.

[14] Onyeike, E.N. and Oguike, J.U. (2003) Influence of Heat Processing Methods on the Nutrient Composition and Lipid Characterisation of Groundnut (Arachis hypogaea) Seed Pastes. Nigeria Society for Experimental Biology, 15, 34-43,

[15] Otori, A.A. and Mann, A. (2014) Determination of Chemical Composition, Minerals and Anti Nutritional Factors of Two Wild Seeds from Nupeland, North Central Nigeria. American Journal of Chemistry and Application, 1, 20-26,

[16] Adane, T. Shimelis, A. Negussie, R. Tilahun, B. and Haki, G.D. (2013) Effect of Processing Method on the Proximate Composition, Mineral Content and Antinutritional Factors of Taro (Colocasia esculenta, L.) Grown in Ethiopia. African Journal of Food, Agriculture, Nutrition and Development, 2, 7383-7395. 